\title{
Reducing the energy intensity of lift irrigation schemes of Northern Tajikistan- potential options
}

\author{
Akmal Kh. Karimov ${ }^{\mathrm{a}, *}$, Vladimir Smakhtin ${ }^{\mathrm{b}}$, Aziz A. Karimov ${ }^{\mathrm{c}}$, Khalim Khodjiev ${ }^{\mathrm{d}}$, \\ Sadyk Yakubov ${ }^{\mathrm{e}}$, Alexander Platonov ${ }^{\mathrm{a}}$, Mirzaolim Avliyakulov ${ }^{\mathrm{f}}$ \\ a International Water Management Institute (IWMI), Central Asia Regional Office, 123, Building No. 6, Osiyo Street, Tashkent 100000, Uzbekistan \\ b International Water Management Institute (IWMI), Colombo, Sri Lanka \\ c International Maize and Wheat Improvement Center, Ankara, Turkey \\ ${ }^{\mathrm{d}}$ Water Management Authority of the Sughd Province (Sughd OblVodhoz), Khodjent, Tajikistan \\ e The Northern Geology Complex Expedition, The Board of Geology, Kairakum, Sughd province, Tajikistan \\ f Tashkent State Agrarian University, Tashkent, Uzbekistan
}

\section{A R T I C L E I N F O}

\section{Keywords:}

Energy intensity

Conjunctive use

Pump irrigation

Groundwater

Tajikistan

\begin{abstract}
A B S T R A C T
Since the 1960 and 1970s, multi-stage pump stations have been widely used in northern Tajikistan in the Syrdarya River midstream to lift water for irrigation. However, the obsolete pump stations often fail to provide a stable water supply and require costly renovation. On the one hand, the high-energy intensity of the water supply negatively affects the sustainable operation of water authorities responsible for running the pump stations. On the other hand, payments for water delivery services are low and do not cover even electricity charges for operation of the pump stations. This results in an unreliable water supply that in turn causes low crop yields and economic losses to farming communities. Currently, the government of Tajikistan and donor agencies have acknowledged the severity of the problem and are looking for potential alternative strategies. Identifying and understanding the water and energy linkages and putting efforts into the resource efficiency improvements could bring win-win outcomes. In this context, this research examines potential alternatives of reducing the energy intensity of the lift irrigation schemes with the purpose of increasing crop production and farmers' income in northern Tajikistan.
\end{abstract}

\section{Introduction}

Lift irrigation schemes installed from the 1960s to the 1980s cover a significant area of the agricultural land in arid and semi-arid regions, including in China, Myanmar, India and Central Asian (CA) countries [1-4]. After four to five decades of utilization of lift irrigation schemes in developing countries, most of them require replacement, upgrading, and maintenance; for example, $35 \%$ of the pumping stations need replacement or repair in Tajikistan [5]. While these demand heavy investments over the years in order to increase the effective operation of irrigation schemes and contribute to better use of scarce resources, it is not considered the best cost-effective strategy for governments.

It is important to sustain efficient water and energy supply, boost crop productivity, and maintain smooth operation of the irrigation infrastructure under growing resource costs. Besides, increasing competition for water and energy in agriculture, industry, and other sectors necessitates efficient and sustainable management of water and energy resources $[6,7]$ in the context of development challenges [8]. Recent studies have emphasized the significance of the water, energy, and food nexus concept [9] in numerous settings [10-15]. The nexus approach highlights the prevailing interlinkages and attempts to quantify them in order to consider alternative strategies and policy options (e.g. [1618]) to sustainably and efficiently manage limited resources.

The CA region has one of the largest irrigation schemes in the world [19] which were built during the Soviet period. The region comprises of five former Soviet Union countries, including Uzbekistan, Kazakhstan, Turkmenistan, Tajikistan and Kyrgyzstan. The total area of the region is 4 million $\mathrm{km}^{2}$ with the population of 65 million people. The CA region includes also the Aral Sea basin, which is a transboundary river basin [20]. Two key resources such as water and energy are considered one of the most valuable resources of the region. They are also CA's most pre-eminent challenges because of shared transboundary rivers Amudarya River and Syrdarya River - flowing to Aral Sea. Two upstream countries of CA, Tajikistan and Kyrgyzstan are situated in the catchment area of these rivers; three downstream countries, Kazakhstan, Turkmenistan and Uzbekistan are located in the zone of

\footnotetext{
* Corresponding author

E-mail address: akmal.karimov.58@mail.ru (A.K. Karimov).
} 


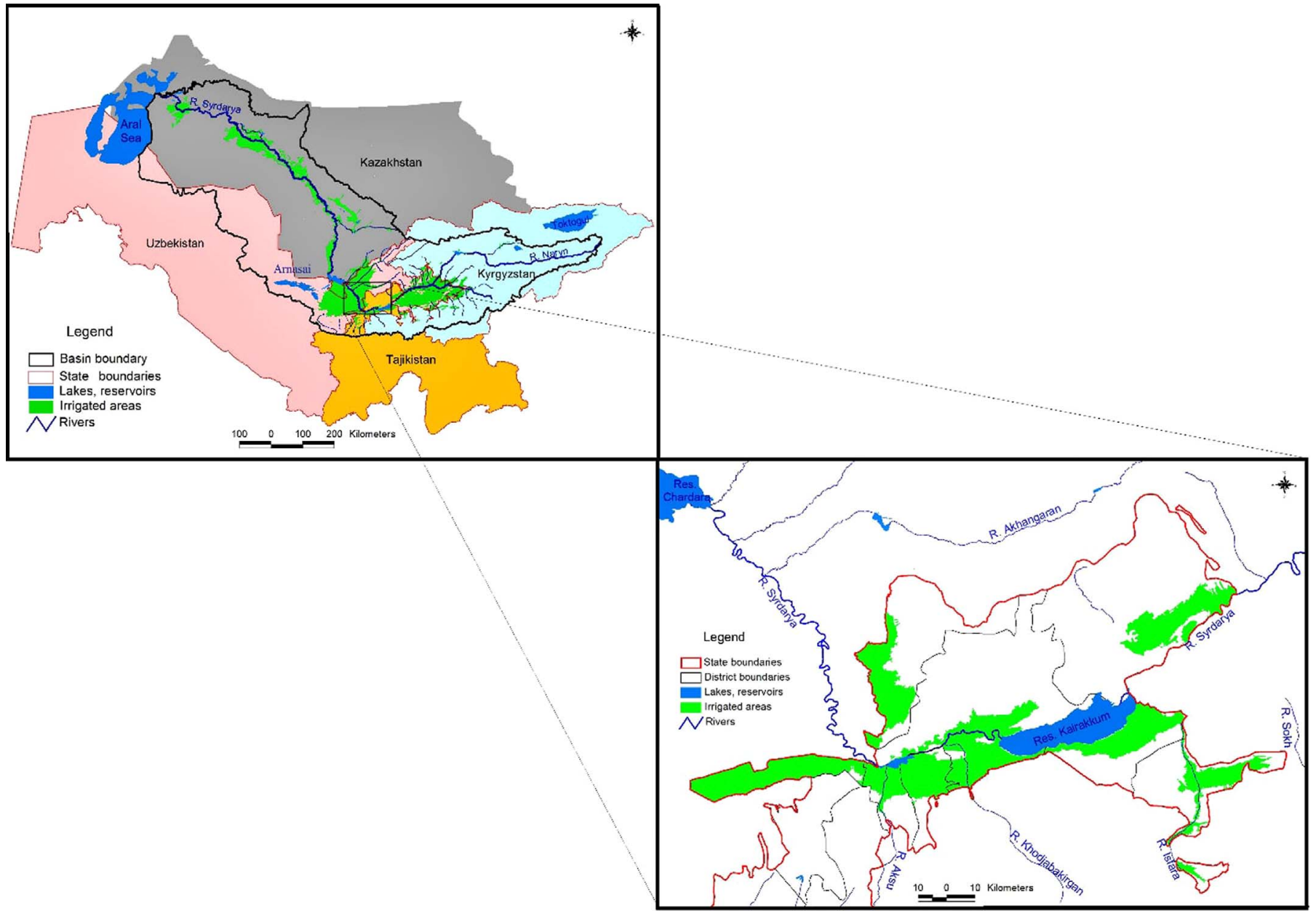

Fig. 1. Map of northern Tajikistan.

International Water Management Institute (IWMI) GIS database (Platonov, pers. comm., 2015).

utilization of water resources.

This study focuses on lift irrigation schemes that supply water from rivers located at lower elevations to agricultural land at higher elevations with a series of multi-stage cascade pump stations. The irrigation systems within the Bukhara region and the Karshi Steppe (both located in Uzbekistan) as well as Sughd province (northern Tajikistan) are examples of such schemes. Over time, the water supply in these schemes has become more energy-intensive, and as a result, provision of a reliable energy supply has become more expensive. Currently, there is a need to explore alternative strategies to reduce water demand and energy use intensity in these areas. This work aims to explore and discuss the potential for improving the performance of lift irrigation schemes through conjunctive use of local water resources, including small river flows and groundwater in northern Tajikistan (see Fig. 1).

\section{Lift irrigation schemes in northern Tajikistan}

Agriculture in Tajikistan constitutes 24\% of GDP, and about $66 \%$ of the labor force is employed in this sector [21]. Major agricultural commodities include cereals (mostly wheat) and cotton, and to a lesser extent perennial crops and vegetables. While the country has abundant surface water resources [20], agriculture incurs heavy lift irrigation costs to bring water to fields [22]. The overall irrigated area supplied by pumping water is $40 \%$ of the total, or about 300,000 ha [5]. In northern Tajikistan, irrigation is mostly based from the water resources of the Syrdarya River [20], which incur the highest level of pumping. When pumping schemes were built during the Soviet period, the value of energy was set far below its economic cost (see e.g. [19]), and productivity as well as cost recovery were not considered important [23]. Currently, the government of Tajikistan spends more than 700 million (M) kWh of electricity per year to lift about $1355 \mathrm{Mm}^{3}$ of water of Syrdarya River for irrigation purposes in northern Tajikistan (Khodjiev, Sughd OblVodhoz, pers. comm., 2012).

The Sughd province in northern Tajikistan covers about 25.2 thousand $\mathrm{km}^{2}$ and is located in the midstream of the Syrdarya River basin. It has a population of about 2.5 million, with about $75.3 \%$ of that number living in rural areas [24]. Agriculture is a backbone of the province and greatly relies on irrigation. It has a continental semi-arid climate with natural conditions that are highly dependent on elevation. In the highlands, the average temperature ranges from 23 to $30{ }^{\circ} \mathrm{C}$ in July and $-1-3{ }^{\circ} \mathrm{C}$ in January. The average annual air temperature is above $10^{\circ} \mathrm{C}$ (i.e., favorable for the cultivation of arable crops) for 200 230 days per year. The long-term annual precipitation ranges from $100 \mathrm{~mm}$ to $250 \mathrm{~mm}$, and $90 \%$ of the rainfall occurs from October to May. Climate conditions at altitudes below 850-900 m above sea level (masl) are favorable for cotton cultivation, 1,400-1600 masl for grapes, and 2,350-2550 masl for apricots. Winter wheat, the most important food crop, can be grown at all elevations. However, winter wheat in lift irrigation areas is highly affected by a lack of irrigation water supply in the cropping season.

The irrigated soils are largely grey and sierozem soils at altitudes of 400 to 1500 masl and light brown soils at altitudes of 1500 to 2800 masl. The total irrigated area of northern Tajikistan is 279,000 ha; $61 \%$ of the land requires lift irrigation, $25 \%$ is under gravity irrigation, and the remaining $14 \%$ uses water from both, lift and gravity irrigation 


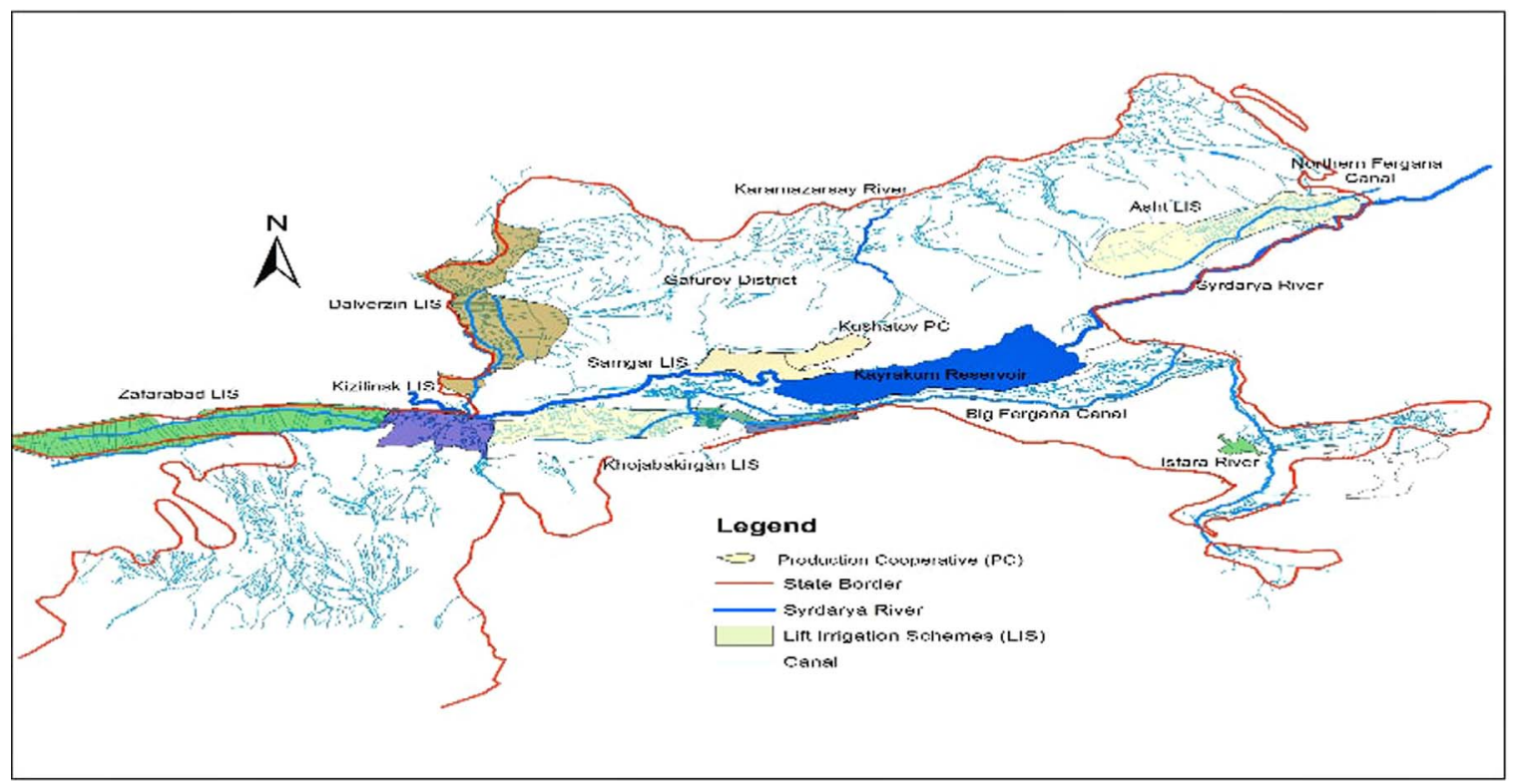

Fig. 2. Lift irrigation schemes of northern Tajikistan.

International Water Management Institute (IWMI) GIS database (Platonov, pers. Comm., 2015).

schemes. The main source of water for lift irrigation is the Syrdarya River, which flows at low altitudes. Several pump stations have been installed on the Kairakum Reservoir (Fig. 2), which was built in the 1970s at the outlet of the upstream Fergana Valley to regulate the flow of the Syrdarya River for midstream uses.

There are also local sources of irrigation water that include small rivers, temporal water courses, transboundary canals and groundwater. Small rivers (e.g. Isfara, Khodjabakirgansai, Aksusai, Karamazarsai and Tuyubuguzsai) inflowing from the upstream country, Kyrgyzstan, mainly during the spring and summer months are fully utilized for irrigation. Originally, only the seepage from the river channels and precipitation infiltration recharged the aquifers. Later, with the development of lift irrigation in the highlands and foothills, leakage from canals and infiltration from the irrigated fields became the primary sources of groundwater recharge.

Small rivers are the source of gravity irrigation in the upper part of the foothills. The upper stages of lift irrigation, which are located below the gravity zone, represent the mixed zone, which gets its water supply from small rivers in water-abundant years and from the lift system during water-scarce years (Khodjiev, Sughd OblVodhoz, pers. comm., 2010), described by [25]. In some lift irrigation schemes such as Samgar, the water shortage in the upper lift stages is compensated also by well irrigation. Groundwater extraction for irrigation at the beginning of summer reduces the groundwater storages. It is compensated for later in the second half of summer by irrigation water losses, partly filling up the groundwater storages and partly forming the return flow to the Syrdarya River. The gradual deterioration of the pump stations, especially over the last two decades, has reduced the irrigation water lift to the study area and decreased the return flow to the river, with less effect on groundwater storages.

As illustrated in Fig. 3, the annual water intake for irrigation between 1990 and 2012 decreased from $4100 \mathrm{~mm}^{3} / \mathrm{yr}$ to $2200 \mathrm{~mm}^{3}$ / yr. The available data from the Water Authority of Sughd province showed that within the time period from 1990 to 2012, the highest decline of power supply to run the pump stations was recorded from 1993 through 2004, when it fell by $31 \%$ and caused a reduction of irrigation water supply at the Water User Association (WUA) level by $33 \%$. During this period, the area of irrigated land decreased by 18,729 ha. Water delivery for irrigation in the rest of the area was reduced from 12,850 to $9113 \mathrm{~m}^{3} / \mathrm{ha}$, which has led to high economic losses for a main part of rural population involved in agriculture. This



Fig. 3. Water intake for irrigation in northern Tajikistan. (Khodjiev, Sughd OblVodhoz, pers. comm., 2015).

is especially relevant to farmers growing winter wheat in the lift irrigated areas. The water authorities often stop the pump stations from October through March because of high energy prices during this period. Lack of irrigation water in October, during sowing period of wheat, and in March, when the plants start re-growing result in low yields of the crop. Due to these reasons, there is an inverse relationship between wheat yields and the area under lift irrigation as can be seen in Fig. 4.

\section{Materials and methods}

\subsection{Calculations}

a) The energy intensity per $\mathrm{m}^{3}$ of water lifted was estimated using the following formula:

$P_{c}=\frac{P}{W}$

where: $P_{c}=$ energy consumption per cubic meter of water lifted $\left(\frac{k W h}{m^{3}}\right)$,

${ }^{m^{3}} P=$ energy consumption for operation of a pump station $(k W h)$, $W=$ water lifted by the pump station $\left(\mathrm{m}^{3}\right)$.

b) The energy intensity per hectare of the irrigated area was calculated as follows:

$P_{w}=\frac{P}{w}$ 


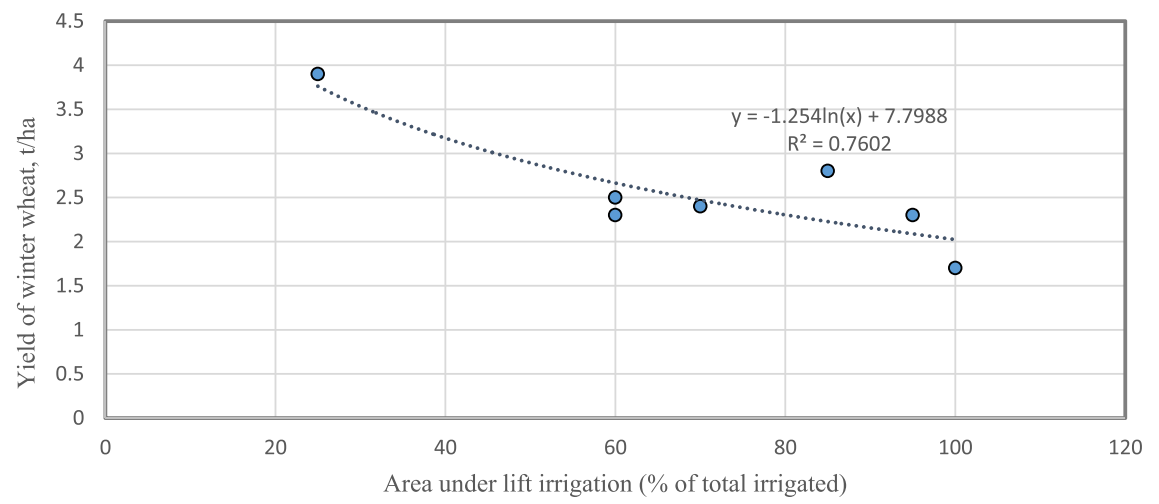

Fig. 4. Yield of winter wheat as affected by lift irrigated area (in \% to total irrigated) for seven districts of northern Tajikistan (average for 2005-2012). Authors estimates based on the yield data from Sughd OblVodhoz (Khodjiev, Sughd OblVodhoz, pers.comm., 2015).

where: $P w=$ energy consumption per ha of the irrigated area $\left(\frac{k W h}{h a}\right)$, $w=$ the area of the irrigated land under the lift irrigation $(h a)$.

c) The energy cost return parameter was calculated using the following formula:

$E C R=\frac{c w s}{c e s}$

where: $E C R=$ energy cost return parameter,

$c w s$ = farmer payments for water delivery services (TJS) to

Water Authorities,

ces $=$ payment for energy consumption for operation of the pump station (TJS), which

Water Authorities have to transfer to the Ministry of Water Resources.

ECR is estimated for operation and maintenance ( $\&$ \& $)$ of the pump stations only. In case of well irrigation, farmers pay for electricity consumed in the operation of wells, and that is why ECR $=1$.

d) Total payment for water delivery services was calculated as follows:

$c w s=W_{s}^{*} w f$

where: $W s=$ water delivered to the WUA gate $\left(\frac{m^{3}}{h a}\right)$, $\left(\frac{k W h}{m^{3}}\right)$

$w f=$ fees for water delivery services per $\mathrm{m}^{3^{h a}}$ of water supplied

Water delivery services up to farm gates are provided by WUAs collecting irrigation fees $\left(0.0177 \mathrm{TJS} / \mathrm{m}^{3}\right)$ from farmers based on the area of irrigated land [5]. According to [20], irrigation fees are set very low (2-6 times less than required), which is not sufficient to sustain irrigation and drainage system maintenance costs.

e) The cost of energy consumed for operation and maintenance of the pump station was calculated using the following formula:

ces $=P^{*} e f$

where: ef $=$ charges for energy used for irrigation $\left(\frac{T J S}{k W h}\right)$.

The electricity consumption cost for irrigation water supply varies depending on the time of year. During summer cropping season (April - October), the electricity fee is at $0.0188 \mathrm{TJS} / \mathrm{kWh}$ and increases three times from October to March. The calculations assume that WUAs collect $100 \%$ of fees for water delivery services.

All these parameters are estimated for each lift stage separately, and as a whole for selected lift irrigation projects. These lift irrigation projects include Samgar Lift Irrigation Scheme on the right bank of the Syrdarya River, Khodjabakirgan (KhB) Lift Irrigation Scheme, and Dihmai Lift Irrigation Scheme on the left bank of the Syrdarya River.

\subsection{Data sources}

The parameters were estimated using data obtained from the provincial Water Authority. The data on the energy consumed for operation and maintenance of the pump stations, the volumes of water lifted by the pump stations, and water delivered to WUAs' gates were obtained from the Sughd Province Water Authority ('Sughd Oblvodhoz') of Tajikistan (Khodjiev, Sughd OblVodhoz, pers. comm., 2012, 2014; Korydjumaev, Gafurov District Water Authority, pers. comm., 2012, 2014). The data collected from Sughd Oblvodhoz also included characteristics of the pumps, power consumption, lift heights, and irrigated areas for each lift stage of the pump stations.

The provincial Water Authority periodically estimates the conveyance efficiency of all canals, including those on farms, using flow measurements. These conveyance efficiency parameters were used to estimate losses at the canal and farm levels.

\subsection{Procedure}

During 2012-2013, the energy intensity of lift irrigation and groundwater irrigation were measured in the Kushatov Production Cooperative, located in the Samgar Lift Irrigation Scheme. The cooperative had an area of 2259 ha, including 1315 ha of irrigated land, of which 940 ha were under perennial crops, orchards, and grapes. Overall, there were 42 farms in the cooperative. Each of them had an area in the range of 50 ha to 150 ha. More than $65 \%$ of the irrigated land relied on groundwater irrigation, and the remainder used lift irrigation from the Syrdarya River. The cooperative had a total of 43 wells, with yields ranging from 10 to $43 \mathrm{l} / \mathrm{s}$.

In the first lift stage, irrigation water supply to farm gates in this Cooperative was monitored on a daily basis throughout the summer of 2012. The study compared two pilot farms located in the first lift stage zone and third lift stage of the Samgar lift irrigation scheme, respectively, and two pilot farms using well irrigation only. The input use at four pilot farms and the associated costs were monitored for each crop on a daily basis.

In the second lift stage, the amount of irrigation water available for crops was compared with potential evapotranspiration (ET) using the FAO method [26,27] for selected pilot farms. Based on the applied farming practices data and associated costs, net profits of farmers were calculated separately for each crop, grown at the pilot farms.

In the final stage, the following two alternative strategies were analyzed: traditional approach to the rehabilitation of lift irrigation schemes, based on replacing pumps and lining canals and increasing water as well as energy fees; redesigning energy-intensive parts of lift irrigation projects based on conjunctive use of available local water resources, including small river flows and groundwater. 


\section{Results}

\subsection{Energy intensity of lift irrigation schemes}

The energy intensity of water pumping within the lift irrigation scheme increases with each lift stage because of sequential pumping of the same water. For example, in 2012 in the Samgar Lift Irrigation Scheme, the actual energy intensity increased from $0.42 \mathrm{kWh} / \mathrm{m}^{3}$ at the first lift stage to $0.57 \mathrm{kWh} / \mathrm{m}^{3}$ at the second lift stage, and to $0.82 \mathrm{kWh} /$ $\mathrm{m}^{3}$ at the third lift stage (Fig. 4). A basic theoretical relationship shows that the energy required to lift $1 \mathrm{~m}^{3}$ of water (with a density of $1000 \mathrm{~kg} / \mathrm{m}^{3}$ ) to a height of $1 \mathrm{~m}$ with $100 \%$ efficiency is $0.0027 \mathrm{kWh}$ [28]. Considering that the height of water lift is $67 \mathrm{~m}$ at the first stage, $47 \mathrm{~m}$ at the second stage, and $44 \mathrm{~m}$ at the third stage, the energy intensity for lifting $1 \mathrm{~m}^{3}$ of water to the height of $1 \mathrm{~m}$ is estimated to be $0.0062 \mathrm{kWh}$ at the first pump station (PS1), $0.0033 \mathrm{kWh}$ at the second pump station (PS2), and $0.0057 \mathrm{kWh}$ at the third pump station (PS3). Therefore, the energy intensity of lifting water at each pump station separately is estimated as $0.44,0.82$ and $0.47 \mathrm{kWh} / \mathrm{m}^{3}$ for the first, second, and third lifts, respectively.

This data shows the scope for reducing energy use intensity through the renovation of pump stations and rehabilitation of lift canals. If the renovation of pump stations of the first and third lifts increases efficiency to 0.82 , which is the efficiency achieved at the pump station of the second lift, then the actual energy required to lift $1 \mathrm{~m}^{3}$ of water would be $0.22,0.375$, and $0.52 \mathrm{kWh}$ for the first, second, and third lifts, respectively. It should be noted that energy intensity for groundwater extraction in the upper lift stage zone is $0.26 \mathrm{kWh} / \mathrm{m}^{3}$ (Fig. 5). Thus, even after expensive renovation of the lift irrigation system, the energy requirements at the second and third lifts would be by $44 \%$ and two times higher, respectively, than the energy required for pumping groundwater. We have followed a similar analysis for the selected three lift irrigation schemes using data from 2014 (Table 1).

The data presented in Table 1 shows that the energy intensity per $\mathrm{m}^{3}$ of water lifted is increasing from the lower stage to the next upper stage of water lift. The water supply from the pump stations at WUA gates ranges widely from 3687 to $14,189 \mathrm{~m}^{3} / \mathrm{ha}$, depending on the lift stage and the availability of other sources of water. Payments for water supply from the pump stations vary from 20 to 45 US\$/ha, except in cases when additional water is available from other sources or applied deficit irrigation. The energy intensity per hectare, increasing under high irrigation applications and at the upper lift stage, was on average 3413, 5864, and $5308 \mathrm{kWh} / \mathrm{ha}$ for the Samgar, Dehmai, and KhB lift irrigation schemes, respectively.

The cost of energy per hectare ranged from 12 US\$/ha to 51 US $\$ /$ ha, except two cases where additional water is supplied from local

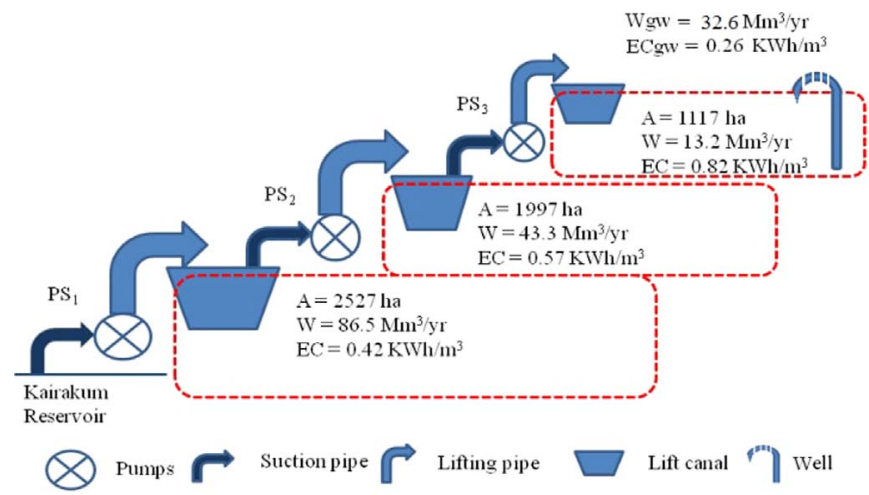

A - irrigated area, $\mathrm{W}$ - water lifted by pump station, EC - energy consumption for lifting water, Wgw - groundwater extraction, ECgw - energy consumption for groundwater extraction, PS1 - pump station of first lift, PS2 - pump station of second lift, PS3 pump station of third lift

Fig. 5. Energy use intensity for water pumping in the Samgar lift irrigation scheme. Authors estimates based on field data. sources. The low cost of energy per ha in the case of the third lift stages of Samgar system could be attributable to using in addition groundwater.

The ECR varied between irrigation projects in terms of reduction from the first stage to upper stages of the lift irrigation schemes. A value of ECR of less than one means that energy cost is not compensated for by water delivery service fees. These estimates show that the payments for water delivery services may compensate for the actual cost of electricity for the operation of the first stage pump station of Dehmai system, and for the first and the second lift stages of KhB and Samgar systems, respectively. In the upper lift stages, the payments for water do not even cover the actual cost of electricity.

\subsection{Water and energy efficiency at farm level}

The analysis of selected farms of Kushatov Farm Union did show a difference in water supply between farms using water from Samgar Lift Irrigation Scheme and groundwater. Fig. 5a and b show water delivery to the farm gates for the first and third lift stage areas, respectively.

The data in Fig. 6a shows that the farmers located in the first lift zone had a surplus water supply with almost no irrigation interruptions. Water supply exceeded the irrigation requirements of main crops. Intercropping and double-cropping were widely practiced by farmers. The total irrigation applications were at $13,200 \mathrm{~m}^{3} / \mathrm{ha}$. However, this was different in the third lift zone (Fig. 6b), where the farmers in the third lift irrigation zone received water two weeks later than farmers in the first lift zone. There were frequent interruptions in water supply from June to September; the total irrigation applications amounted to $8800 \mathrm{~m}^{3} / \mathrm{h}$. The amount of water supplied was close to the irrigation requirements of the crops at the seasonal level, but not on a monthly basis. Irrigation of crops was based on supply rather than demand. For example, water supply was higher in the April/May period compared to the July/August period while crop water requirements were lower. The farmers were only able to irrigate their main crops under such conditions. As shown in Fig. 7, farmers using groundwater for irrigation used a different strategy.

The farmers using groundwater for irrigation had a uniform uninterrupted water supply except for a few days owing to power cuts. Fig. 7 a shows that water supply met crop water requirements during the entire crop vegetation season, except in mid-summer. In periods of power outage, pump restoration or high-water demand, farmers often purchased water from neighboring farms as recorded in August (Fig. 7b). The lack of access to other sources of water induced the farmers to utilize groundwater more effectively. Total irrigation applications were 8900 and $6050 \mathrm{~m}^{3}$ /ha, respectively.

The farmers received water from the lift irrigation scheme at the cost of US $\$ 3.7$ for $1000 \mathrm{~m}^{3}$. The farmers using wells paid for electricity at US $\$ 3.9 / 1000 \mathrm{kWh}$ to utility companies, which made US $\$ 1 / 1000 \mathrm{~m}^{3}$ of water received. Non-uniform water distribution under lift irrigation caused water shortages at the ends of the canals, reduced crop yields, and affected farm incomes. The data collected from pilot farms confirms that the farmers from the third lift irrigation zone faced challenges more often compared to the farmers from the first lift irrigation zone (Table 2).

The data presented in Table 2 indicates that farmers producing apricots and grapevine incurred economic losses under water-scarce conditions in the third lift irrigation zone. Overall in the Kushatov Production Cooperative, yields of cotton and grapevines were low even under reliable water supply conditions (Rahmonberdiev, Kushatov Production Cooperative, pers. comm., 2012, 2013). Farmers that produced vegetables, melons, and rice achieved higher yields and income under reliable water supply conditions, and quince proved to be a low water-consumptive crop bringing high net profits for farmers. High irrigation rates at the farm in the first lift zone indicate significant losses of irrigation water, which became a main source of groundwater recharge and drainage flow from the project area. The irrigation 
Table 1

Performance parameters of selected lift irrigation schemes. Data for 2014. Exchange rate: 1 USD = 5.6 TJS

Source: Authors estimates based on field data

\begin{tabular}{|c|c|c|c|c|c|c|c|}
\hline Pump stations & Lift stage & Energy intensity per $\mathrm{m}^{3}$ & Water supply per ha & Energy intensity per ha & Fees for water supply & Cost of energy & Energy cost return \\
\hline & & $\mathrm{kWh} / \mathrm{m}^{3}$ & $\mathrm{~m}^{3} / \mathrm{ha}$ & KWh/ha & USD/ha & USD/ha & TJS/TJS \\
\hline Samgar 1 & 1 & 0.34 & 10670 & 3617 & 34 & 14 & 2.39 \\
\hline Samgar 2 & 2 & 0.49 & 6209 & 3047 & 20 & 12 & 1.65 \\
\hline Samgar 3 & 3 & 0.67 & 3687 & 2467 & 12 & 10 & 1.21 \\
\hline Samgar Project & & 0.44 & 7708 & 3413 & 24 & 13 & 1.83 \\
\hline Dehmai 1 & 1 & 0.67 & 9269 & 6243 & 29 & 24 & 1.20 \\
\hline Dehmai 2 & 2 & 1.08 & 4678 & 5061 & 15 & 20 & 0.75 \\
\hline Dehmai 3 & 2 & 0.93 & 14189 & 13151 & 45 & 51 & 0.87 \\
\hline Demhai 4 & 2 & 1.25 & 5576 & 6966 & 18 & 27 & 0.65 \\
\hline Dehmai Project & & 0.91 & 6414 & 5864 & 20 & 23 & 0.89 \\
\hline KhB 1 & 1 & 0.28 & 7801 & 2168 & 25 & 8 & 2.91 \\
\hline KhB 2 & 2 & 0.52 & 13000 & 6799 & 41 & 27 & 1.55 \\
\hline KhB 3 & 3 & 0.81 & 11052 & 8987 & 35 & 35 & 1.00 \\
\hline KhB Project & & 0.50 & 10714 & 5308 & 34 & 21 & 1.63 \\
\hline
\end{tabular}

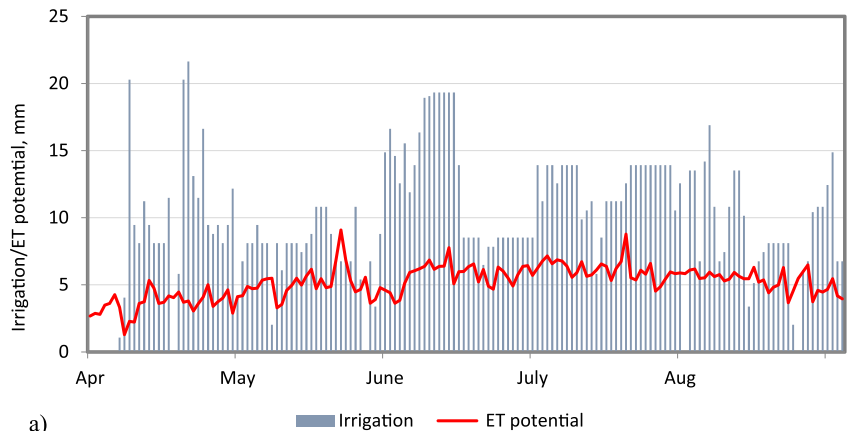

a)

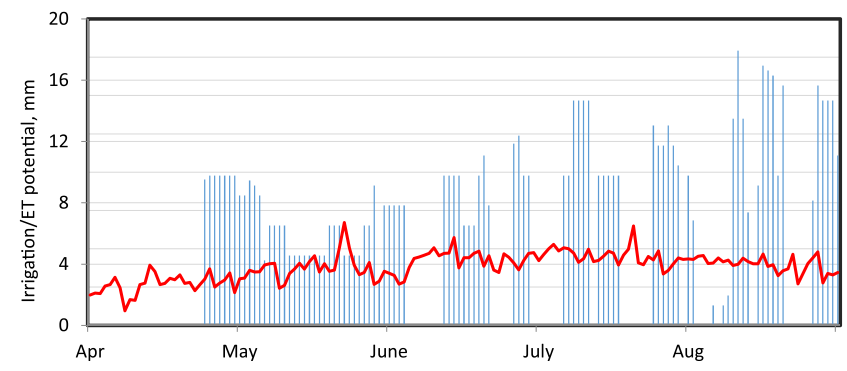

b)

Irrigation —ET potential

Fig. 6. Water delivery to farm gates under lift canal irrigation at the pilot farms of the Kushatov Production Cooperative in 2012: a) first lift zone, and b) third lift zone. Authors field data.

application at the farm level averaged 13,183 and $8858 \mathrm{~m}^{3} / \mathrm{ha}$, respectively, at the farms located in the first and the third lift stage zones. Because of high irrigation applications for some of the crops, the energy intensity per hectare was quite high, even in the first lift stage zone. The average energy intensity was $5537 \mathrm{kWh} / \mathrm{ha}$ and $7264 \mathrm{kWh} /$ ha at the farms located in the first and the third lift stage areas.

The farmers from the first lift stage area received a net profit of US $\$ 6557$ from 63.9 ha, or US $\$ 103 /$ ha. The expected payment for water supply services (if $100 \%$ collected) totaled US $\$ 49 /$ ha, or $47 \%$ of net profit, which is quite high. The farmers growing mainly cotton in the third lift irrigation zone incurred a loss of US\$5978 from 112.5 ha, or US $\$ 53 /$ ha. The average irrigation rate at the farm was $8858 \mathrm{~m}^{3} / \mathrm{ha}$, and water fees totaled US $\$ 32 /$ ha. Low incomes of farmers associated mainly with cultivation of cotton, as well as high irrigation water applications, are the main reasons for low irrigation fee collection rates at the farm union. In case of groundwater irrigation practicing farmers, cotton production generated minor profits (Table 3 ). a)

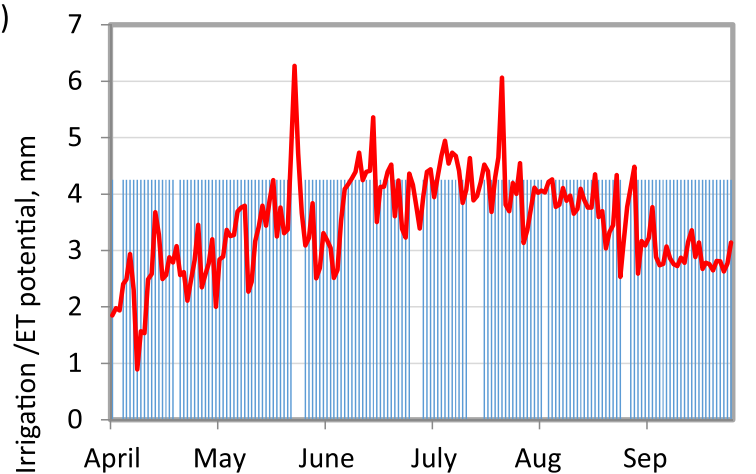

b)

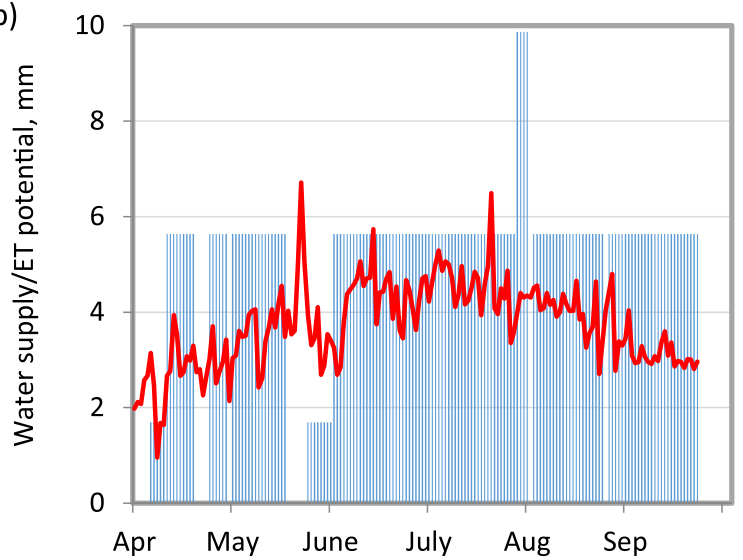

Fig. 7. ET potential (red line) and water delivery to farm gates under groundwater irrigation for (a) grapevine, and (b) cotton production (blue line) in pilot farms of the Kushatov Production Cooperative in 2012. (For interpretation of the references to color in this figure legend, the reader is referred to the web version of this article.). Authors field data and estimates.

The irrigation applications were 8933 and $6052 \mathrm{~m}^{3} /$ ha on average for cotton production and for grapevine production farms, respectively. The energy intensity was estimated at 2322 and $1574 \mathrm{kWh} / \mathrm{ha}$ for cotton and grapevine production farms, respectively. These estimates show that the energy intensity of crop production is much less at farm using groundwater as compared to the farms using water from the lift irrigation scheme. Because of higher incomes received from apricots, the farmer gained US\$9431 from 62 ha, or 152 US $\$ /$ ha. The expected payment for water delivery services (if $100 \%$ paid) totaled US $\$ 9 /$ ha, or $6 \%$ of net profit. The other farmer growing mainly grapevine and young 
Table 2

Net profits of farmers from crop cultivation under lift canal irrigation in the Samgar irrigation area. Source: Authors field data and estimates

\begin{tabular}{|c|c|c|c|c|c|c|c|}
\hline Crop & $\begin{array}{l}\text { Irrigation rate } \\
\mathrm{m}^{3} / \mathrm{ha}\end{array}$ & $\begin{array}{l}\text { Energy expenses } \\
\mathrm{kWh} / \mathrm{ha}\end{array}$ & $\begin{array}{l}\text { Payment for water services } \\
\text { US } \$ / \text { ha }\end{array}$ & $\begin{array}{l}\text { Crop production cost } \\
\text { US } \$ / \text { ha }\end{array}$ & $\begin{array}{l}\text { Yield } \\
\text { t/ha }\end{array}$ & $\begin{array}{l}\text { Income } \\
\text { US } \$ / \text { ha }\end{array}$ & $\begin{array}{l}\text { Profit } \\
\text { US\$/ha }\end{array}$ \\
\hline \multicolumn{8}{|l|}{ First lift irrigation zone } \\
\hline Apricot of 1998 planting & 7540 & 3167 & 28 & 142 & 1.2 & 197 & 55 \\
\hline Alfalfa & 14,090 & 5918 & 52 & 573 & 6 & 630 & 57 \\
\hline Vegetables & 17,684 & 7427 & 65 & 2574 & 18 & 3105 & 532 \\
\hline Melon & 21,677 & 9104 & 80 & 674 & 12 & 1008 & 334 \\
\hline Sorghum & 18,051 & 7581 & 67 & 763 & 10 & 839 & 76 \\
\hline Rice & 40,089 & 16,837 & 148 & 888 & 3 & 1261 & 372 \\
\hline \multicolumn{8}{|l|}{ Third lift irrigation zone } \\
\hline Cotton & 10,128 & 8305 & 40 & 1182 & 1.9 & 989 & -193 \\
\hline Apricot & 3640 & 2985 & 14 & 165 & 1 & 160 & -5 \\
\hline Grapevine & 5248 & 4303 & 21 & 173 & 0.6 & 90 & -83 \\
\hline Maize for grain & 9310 & 7634 & 36 & 696 & 4 & 882 & 186 \\
\hline Maize for silage & 9060 & 7429 & 35 & 603 & 18 & 735 & 133 \\
\hline Alfalfa & 11,030 & 9045 & 43 & 535 & 6.5 & 692 & 158 \\
\hline Quince & 5120 & 4198 & 20 & 191 & 4 & 560 & 369 \\
\hline Sorghum & 9680 & 7938 & 38 & 799 & 10 & 840 & 41 \\
\hline
\end{tabular}

apricots using groundwater still gained US $\$ 2428$ from 28 ha, or 87 US $\$ /$ ha (Table 3). The expected payment for water totaled US $\$ 6 /$ ha, or $7 \%$ of net profit. The estimates presented show that farmers using groundwater charged for power supply pay 3.5 times less than they would pay for irrigation water supplied. The power supply cost per hectare is low, and that is why farmers using well irrigation cover the full operation and maintenance cost of the wells themselves. Another advantage of well irrigation is a good setup of groundwater governance in the production farm, which has the following features:

- wells for irrigation are owned by the cooperative, and farmers operate and maintain the wells on a contractual basis;

- the local Water Authority provides well maintenance services for farmers on a contractual basis;

- farmers pay the cost of the electricity to operate wells to power utilities and cover the maintenance cost of the wells themselves;

- charges for electricity for operation of wells are significantly higher during the inter-season than during the vegetation of crops from 1 April to 1 October; farmers rotate water during periods of high water demand and jointly cover the electricity cost.

The combination of good water governance practices, reliable water supply, and low cost of power supply creates favorable conditions for groundwater development.

\section{Discussion of alternative strategies}

\subsection{Rehabilitation of pump stations and canals}

Currently about $40 \%$ of the pumps do not function in Tajikistan [29]. The flow rates of the functioning pumps are lower than the design flow rates. Consequently, the actual irrigated areas are less than the areas initially developed. Burt [29] highlights that the government of Tajikistan invests 10 times less in $\mathrm{O} \& \mathrm{M}$ of the irrigation systems as compared to investments in advanced irrigation schemes. Based on analyses of the status of the six pumped projects in 2012, he concluded that doubling the investments and improving pumping plant efficiency can improve water reliability at the WUA gates. Estimates of the Sughd Province Water Authority (Khodjiev, pers. comm., 2015) showed the need to invest about 66 M US $\$$ for rehabilitation of pump stations and canals in the Zafarabad Lift Irrigation Scheme in northern Tajikistan, supplying water to a 36,000ha area. This approach may improve the reliability of water supply in lift irrigation areas. At the same time, the investment has to ensure improved water delivery services at low cost, which then have to be reflected in water and energy prices. This study shows that even after rehabilitation work, irrigation in the upper lift stages above the second lift will require high energy expenses. Without considering efficient use of local water resources and redesigning lift irrigation schemes, this approach could be costly for the Government of Tajikistan.

Table 3

Net profits of farmers from crop cultivation under groundwater irrigation in the Samgar irrigation area. Source: Authors estimates

\begin{tabular}{|c|c|c|c|c|c|c|c|}
\hline Crop & $\begin{array}{l}\text { Irrigation rate } \\
\mathrm{m}^{3} / \mathrm{ha}\end{array}$ & $\begin{array}{l}\text { Energy expenses } \\
\mathrm{kWh} / \mathrm{ha}\end{array}$ & $\begin{array}{l}\text { Cost of water supply } \\
\text { US\$/ha }\end{array}$ & $\begin{array}{l}\text { Crop production cost } \\
\text { US } \$ / \text { ha }\end{array}$ & $\begin{array}{l}\text { Yield } \\
\text { t/ha }\end{array}$ & $\begin{array}{l}\text { Income } \\
\text { US\$/ha }\end{array}$ & $\begin{array}{l}\text { Net profit } \\
\text { US\$/ha }\end{array}$ \\
\hline \multicolumn{8}{|c|}{ Groundwater irrigation (cotton production farm) } \\
\hline Cotton & 9313 & 2421 & 9.5 & 1303 & 2 & 1348 & 45 \\
\hline Vegetables & 14,980 & 3895 & 15.3 & 2560 & 15 & 3025 & 465 \\
\hline Maize for silage & 10,263 & 2668 & 10.4 & 457 & 15 & 630 & 173 \\
\hline Apricot & 3939 & 1024 & 4.0 & 75 & 2 & 564 & 489 \\
\hline \multicolumn{8}{|c|}{ Groundwater irrigation (grapevine production farm) } \\
\hline Grapevine & 4288 & 1115 & 4.4 & 75 & 3 & 577 & 148 \\
\hline Apricot & 3055 & 794 & 3.1 & 377 & - & - & -377 \\
\hline Vegetables & 14,480 & 3765 & 14.7 & 2249 & 13 & 2818 & 569 \\
\hline Sorghum & 10,210 & 2655 & 10.4 & 793 & 24 & 840 & 48 \\
\hline Alfalfa & 14,480 & 3765 & 14.7 & 594 & 8 & 840 & 247 \\
\hline
\end{tabular}




\subsection{Conjunctive use of local water resources}

Current irrigation practices in northern Tajikistan form significant return flow from the irrigated land exceeding $30 \%$ of water resources, available for irrigation and aquifers are full. This is because of high leakage from irrigation canals and conventional furrow irrigation practices applied by farmers. Because of the low-efficient water use and undeveloped groundwater, multi-stage pump irrigation covers over $60 \%$ of the irrigated land. Improving efficiency can permit increasing the area under gravity irrigation.

Flow estimates from small rivers that include Khodjbakirgansai, Isfara, Aksu, and Isfanasai show that from $361 \mathrm{Mm}^{3}$ in low-water years to $393 \mathrm{Mm}^{3}$ in high-water years are available for irrigation during the summer crop season. It is believed that introducing water-saving technologies can reduce irrigation applications up to $6000 \mathrm{~m}^{3} / \mathrm{ha}$ on average, which can allow applying gravity irrigation to $60,000-$ 66,000 ha of the agricultural land. This may result in doubling the area under gravity/low-pressure pump irrigation in the small river basins. In some lift irrigation projects with no upstream small river, supplemental irrigation can be applied in the upper lift stage areas for cultivation of pistachios and low water consumptive winter crops. In some cases, such as the Samgar Lift Irrigation Scheme, groundwater development could be an alternative solution to lift irrigation in the upper lift stages.

The lower zone of the lift irrigation schemes is favorable for conjunctive use of groundwater and lift canal water. In this case, groundwater irrigation, which is the usage of the return flow within the area of its origin, in combination with water saving technologies may cover from 67,000-77,000 ha area. In total, the area under gravity/low pressure pump and groundwater irrigation may add up to $127,000-$ 143,000 ha. There may be still 95,000-112,000 ha of land under lift irrigation, which are currently 195,000 ha. The redesigned scheme of irrigation will require less, by about $200 \mathrm{MkWh} / \mathrm{yr}$, power supply. The proposed strategy of water management and introducing water saving technologies may result in lowering the groundwater table and reducing water storage. To avoid the overdraft of groundwater, managed aquifer recharge (MAR) activities need to be planned in advance.

\subsection{Managed aquifer recharge}

The adoption of water-saving technologies may reduce groundwater recharge and cause the decline of the groundwater table. This can be prevented by MAR activities (see also [30]). The hydrogeological conditions of northern Tajikistan, characterized by a combination of wide and naturally well-drained zones with high conductivities and narrow and poorly drained as well as no-drainage zones, are favorable for MAR. Water-bearing deposits have high conductivity in the naturally well-drained zone, and vertical fluxes dominate in the poorly drained and no natural drainage zones [31]. The no-drainage zone forms a natural barrier to the subsurface flows. Temporarily storing the excessive water in the aquifer can ensure long-term and sustainable use of groundwater.

There are two sources of water for MAR in northern Tajikistan: winter flow of small rivers and water transfers through transboundary canals. The winter flow of three main small rivers - Isfara, Khodjabakirgansai and Aksusai - is about $199 \mathrm{Mm}^{3}\left( \pm 20 \mathrm{Mm}^{3}\right)$ on average. The recent shift of the upstream reservoir on the Naryn River, a tributary of the Syrdarya River, from irrigation to hydropower generation has increased the winter flow and reduced the summer flow of the river downstream. There are excessive hydropower releases in the winter at $3000 \mathrm{Mm}^{3}$ /season from the upstream reservoir, which can flood the irrigated land downstream; the transboundary water winter transfers may contribute to storing part of the winter flow underground for summer use. There are two main transboundary canals, the Northern Fergana Canal (NFC) and the Big Fergana Canal (BFC), that deliver water from the Naryn River upstream to the study area. The canals have carrying capacities of $5 \mathrm{~m}^{3} / \mathrm{s}$ and $13 \mathrm{~m}^{3} / \mathrm{s}$, respectively [1]. The annual planned amounts ('limits') of transboundary water transfer from the NFC and the BFC in the summer amount to $71 \mathrm{Mm}^{3}$ and $202 \mathrm{~mm}^{3}$, respectively. In the winter season, there are no planned water transfers, and channels of the canals are dry. During this season, the BFC and NFC canals could be used for transferring winter flows from the Naryn River to the recharge areas in the Syrdarya River midstream. The carrying capacities of the NFC and BFC could even be increased to $11 \mathrm{~m}^{3} / \mathrm{s}$ and $23 \mathrm{~m}^{3} / \mathrm{s}$, respectively, for the tail-end segments. This proposal of close cooperation is different from the scenario of delinking Tajikistan's allocation from the BFC and Uzbekistan's allocation from the Isfara River, advocated by [32]. The proposal highlights the potential for transboundary water transfers in the winter when excess water in the upstream system could be stored underground to cover summer water shortages in the tail-ends of the canals..

Thus, up to $170 \mathrm{~mm}^{3} /$ year and $350 \mathrm{~mm}^{3} /$ year of water from the NFC and the BFC, respectively, could be available via gravity for MAR in northern Tajikistan during the winter. In total, considering small rivers and transboundary canals, the potential winter flow available for MAR is up to $370-550 \mathrm{~mm}^{3}$ /year, which is in the range of potential extractions of groundwater in the lift irrigation zone of northern Tajikistan. The estimates presented above indicate that there is no reason to pump excessive water from the Syrdarya River for irrigation and form high return flows to the river channel. Instead, local water resources can be used more efficiently, and groundwater can be captured within the lift irrigation schemes. The MAR activities can contribute to preventing the potential future depletion of groundwater storages.

\subsection{Incentives and approaches for adoption of the proposed strategy}

Rehabilitation of the lift irrigation schemes requires significant investments from the state budget of Tajikistan. The approach proposed in this study aims to create the potential for improving water and energy efficiency in the studied region. The government can focus on installation facilities for groundwater recharge, such as facilities for flood storage on small rivers and temporary water courses in underground aquifers. As the study showed, this is a less energy- consuming approach that can be used to restore reliable irrigation water supply in lift irrigation areas of northern Tajikistan.

Every year, Tajik migrants send approximately $\$ 2-2.5$ billion US dollars from abroad to Tajikistan, which are utilized to support their families and to invest in small businesses, including farming (see e.g. [33]). According to various sources, between 800,000 - 1000,000 (26.4-43.9\% of economically active population) labor migrants from Tajikistan work abroad [34]. The latest available estimates show that remittances accounted for $29 \%$ of GDP, and Tajikistan was ranked third in the world with respect to the importance of migrant remittances to the economy of a country [35]. The government can concentrate its efforts on providing incentives to the rural population and encourage farmers to invest remittances in water-saving technologies, groundwater development, and improving irrigation infrastructure. These will help farmers to grow high-value crops such as grapes, potatoes, and vegetables. Farmers will be encouraged to grow winter wheat in lift irrigation areas because of timely and sufficient well irrigation, especially during the crop-sowing season. The cultivation of wheat will allow farmers to grow a second crop after the wheat harvesting, which will eventually increase their income from farming.

\section{Concluding remarks}

Inefficient pumping stations with low $\mathrm{O} \& \mathrm{M}$ budgets limit the sustainability of pump irrigation systems in high lift zones in the developing countries. The main strategy advocated by governments for sustainability of lift irrigation schemes is the rehabilitation of pump 
stations and canals, as well as increasing water and energy prices [5]. This is the traditional approach of rehabilitation of the pump stations and irrigation canals, which is considered a costly practice. Current analyses of energy intensity at different lift stages of the selected pump stations presented by the study indicate the possibility of exploring alternative strategies to improve water and energy efficiency with the purpose of increasing crop production and income for farmers. This strategy proposes redesigning energy intensive lift irrigation schemes, especially their upper lift stages. Redesigning the lift irrigation schemes may include improving efficiency and the area of gravity and low-head pump irrigations and the adoption of water-saving technologies. These practices potentially can double the area under gravity irrigation. Groundwater development is another alternative to reduce the energy intensity. Governments can concentrate their efforts on providing incentives to the rural population and direct farmer investments towards water-saving technologies, groundwater development, and irrigation infrastructure. It can focus also on installation of managed aquifer recharge facilities.

Reducing the energy intensity of the lift irrigation schemes in the Syrdarya river basins may contribute to mitigating the competition for water between upstream hydropower and downstream agriculture. The results of the study also indicate the importance of transboundary cooperation, which can eventually increase basin scale water productivity and energy efficiency. The transboundary cooperation can provide multiple opportunities for low-cost water gravity transfers and storage, which can form new basin water management more befitting the new socio-economic environment of Central Asia. Further analyses of energy intensity are required, particularly in relation to water-saving technologies, water governance, input prices, and market opportunities in Central Asia for both energy and agricultural products.

\section{Acknowledgements}

The continuous financial support of this study provided by the Organization of the Petroleum Exporting Countries (OPEC) Fund for International Development (OFID) and, more recently, by the CGIAR Research Program on Water, Land and Ecosystems (WLE) is gratefully acknowledged. The authors are grateful to Mr. Khalim Khodjiev, Deputy Head of the Sughd OblVodhoz and Mr. Sodyk Yakubov, Chief Hydrogeologist of the Northern Complex Geology Expedition under the Board of Geology of Tajikistan for contributions to the paper. Special thanks to Mr. Khabibullo Rahmonberdiev, Agronomist of the Kushatov Production Cooperative, Mr. Ahrullo Korydjumaev, Deputy Head of the Gafurov District Water Authority and Mr. Akmal Akhmedov, Chief Hydrogeologist of the Board of Geology under the Government of Tajikistan for collaboration, providing access to data and a great support.

\section{References}

[1] Beniaminovich EM, Tersitski DK. Current status and future of irrigation development in the Syrdarya River Basin. Irrig Uzb 1975;2:43-190.

[2] Subba RB. Irrigation water management in Gaylegphug Lift Irrigation Scheme; 1978. 〈http://publications.iwmi.org/pdf/H006899.pdf

[3] Doczi J, Callow R, D’Alançon V. Growing more with less. China's progress in agricultural water management and reallocation. Development Progress. Case study report; 2014. 〈http://www.developmentprogress.org/sites/developmentprogress. org/files/case-study-report/china full report - final digital.pdf $>$.

[4] China FAO. Aquastat Data Base. 〈http://www.fao.org/nr/water/aquastat/ countries_regions/CHN/CHN-CP_eng.pdf $\rangle$.

[5] ADB. Republic of Tajikistan: Developing Water Resources Sector Strategies in Central and West Asia. Technical Assistance Consultant's Report. /https://www. adb.org/sites/default/files/project-document/79761/45353-001-tacr-02.pdf); 2013.

[6] Siddiqi A, Anadon LD. The water-energy nexus in Middle East and North Africa. Energy Policy 2011;39(8):4529-40.
[7] Howells M, Hermann S, Welsch M, Bazilian M, Segerstro“m R, Alfstad R, Gielen D, Rogner H, Fischer G, van Velthuizen H, Wiberg D, Young C, Roehrl A, Mueller A, Steduto P, Ramma I. Integrated analysis of climate change, land-use, energy and water strategies. Nat Clim Change 2013;3:621-6.

[8] WEF (World Economic Forum). Water Security: The Water-Food-Energy-Climate Nexus. Island Press, Washington DC. 〈https://www.weforum.org/reports/watersecurity-water-energy-food-climate-nexus); 2011.

[9] FAO. TheWater-Energy-Food Nexus: A New Approach in Support of Food Security and Sustainable Agriculture. Food and Agriculture Organization of the United Nations, Rome; 2014. 〈http://www.fao.org/3/a-bl496e.pdf〉.

[10] Bazilian M, Rogner H, Howells M, Hermann S, Arent D, Gielen D, Steduto P, Mueller A, Komor P, Tol S, Yumkella K. Considering the energy, water and food nexus: towards an integrated modelling approach. Energy Policy 2011:39(12):7896-906.

[11] Hardy L, Garrido A, Juana L. Evaluation of Spain's water-energy nexus. Int J Water Resour Dev 2012;2012(1):151-70.

[12] Hussey K, Pittock J. The energy-water nexus: managing the Links between energy and water for a sustainable future. Ecol Soc 2012;17(1):31.

[13] Ringler C, Bhaduri A, Lawford R. The nexus across water, energy, land and food (WELF):potential for improved resource use efficiency? Curr Opin Environ Sustain 2013;5:617-24.

[14] Rasul G. Food, water and energy security in South Asia: a nexus perspective from the Hindu Kush Himalayan region. Environ Sci Policy 2014;39:35-48.

[15] Jalilov SM, Keskinen M, Varis O, Amer S, Ward FA. Managing the water-energyfood Nexus: gains and losses from new water development in Amu Darya river basin. J Hydrol 2016:6.

[16] Hellegers PJ, Zilberman D, Steduto P, McCornick P. Interactions among water, energy, food and environment: evolving perspectives and policy issues. Water Policy 2008;10(Suppl. 1):1-10.

[17] Scott C, Pierce S, Pasqualetti M, Jones A, Montz B, Hoover J. Policy and Institutional dimensions of the water-energy nexus. Energy Policy 2011 2011;39(10):6622-30.

[18] Chen J, Shi H, Sivakumar B, Peart MR. Population, water, food, energy and dams. Renew Sustain Energy Rev 2016;56:18-28.

[19] Bucknall L, Klytchnikova I, Lampietti J, Lundell M, Scatasta M, Thurman M. Irrigation in Central Asia: social economic and environmental considerations. World Bank.〈http://siteresources.worldbank.org/ECAEXT/Resources/ publications/Irrigation-in-Central-Asia/Irrigation_in_Central_Asia-Full_ Document-English.pdf $>$.

[20] FAO. Irrigation in Central Asia in figures. AQUASTAT Survey-2012. Water Report; 39. Rome, Italy; 2013. 〈http://www.fao.org/3/a-i3289e.pdf .

[21] ADB. Key Indicators for Asia and the Pacific. 46th edition. 〈https://www.adb.org/ sites/default/files/publication/175162/ki2015.pdf); 2015.

[22] Nazirov AA. Development of the water management system in Tajikistan. In: Bayarsaihan T, McKinney D, editors. Past experience and future challenges: cooperation in shared water resources in Central Asia. ADB; 2004. p. 26-31.

[23] Svendsen M, Sharofiddinov H. Needs - Based Budgeting for Irrigation System Management in Tajikistan. Report; 2014. 〈http://pdf.usaid.gov/pdf_docs/ PA00KB82.pdf>.

[24] TAJSTAT. Database: Socio-demographic sector; 2016. 〈http://www.stat.tj/en/ database/socio-demographic-sector/ $\rangle$.

[25] Wegerich K, Kazbekov J, Mukhamedova N, Musayev S. Is it possible to shift to hydrological boundaries? The Ferghana Valley meshed system. Int J Water Resour Dev 2012 1;28(3):545-64

[26] Allen RG, Pereira LS, Raes D, Smith M. Crop evapotranspiration. Guidelines for computing crop water requirements. FAO Irrig Drain Pap 1998;56:300, [FAO, Rome] 〈https://appgeodb.nancy.inra.fr/biljou/pdf/Allen_FAO1998.pdf〉.

[27] Allen RG, Pereira LS, Smith M, Raes D, Wright JL. FAO-56 dual crop coefficient method for estimating evaporation from soil and application extensions. J Irrig Drain Eng 2005;2005(131):2-13.

[28] Rothausen SGSA, Conway D. Greenhouse-gas emissions from energy use in the water sector. Nat Clim Change 2011:1 〈www.nature.com/natureclimatechange).

[29] Burt Ch. Improving Irrigation-Related Electrical Energy Efficiency in Tajikistan. WB. Final Report, 49 p; 2014

[30] Karimov A, Kh, Smakhtin V, Mavlonov A, Borisov V, Gracheva I, Miryusupov F, Akhmedov A, Anzelm K, Yakubov S, Karimov AA. Managed aquifer recharge: a potential component of water management in the Syrdarya River Basin. J Hydrol Eng 2014, [10.1061/(ASCE][HE.1943-5584.0001046, B5014004].

[31] Kozlov SS, Martianova GI. Hydrogeology conditions of the Northern Tajikistan. in: Hydrogeology of USSR. Publisher: 'Nedra', Moscow, Vol. 41: 73-87; 1972.

[32] Pak M, Wegerich K, Kazbekov J. Re-examining conflict and cooperation in Central Asia: a case study from the Isfara River, Fergana Valley. Int $J$ Water Resour Dev 2014;30(2):230-45.

[33] Azzarri C, Zezza A. International migration and nutritional outcomes in Tajikistan. Food Policy 2011 28;36(1):54-70.

[34] ILO. Migrant remittances to Tajikistan: the potential for savings, economic investment and existing financial products to attract remittances; 2010. http:// www.ilo.org/wcmsp5/groups/public/-europe/-ro-geneva/-sro- moscow/documents/publication/wcms_308938.pdf.

[35] World Bank. Annual Remittances Data; 2016. 〈http://www.worldbank.org/en/ topic/migrationremittancesdiasporaissues/brief/migration- $>$ remittances-data. 